\title{
ANALYSIS OF NIGERIA FIRMS, EXPORT MARKETING CONFIGURATION IN THE GLOBAL MARKET
}

\section{Bright C. Opara ${ }^{1}$}

${ }^{\prime}$ Department of Marketing, Faculty of Management Sciences, Rivers State University of Science and Technology, Nigeria

\begin{abstract}
This study is set out to analyze the Configuration (behavior) of Nigerian firms' export marketing in the global market. This can be appreciated from the fact that export play important role in the socio-economic development of nations; in the areas of value creation and facilitate economics of abundance for national development. The data were generated through structured questionnaire administered on sixty exporting firms located in Lagos. The data were statistically subjected to T-tests, employing Analysis of Variance (ANOVA), in Special Packages for Social Sciences (SPSS). The findings revealed that Nigerian exporting firms are patterned into Experimental, Active, and Committed. The findings also showed that Nigeria firms' years of export involvement influence their pattern of export, just as company size and number of employee's impact on firms' categorization of export involvement. The findings of this study are peculiar because it focuses on Nigeria firms involved in export, and give valuable insight on the prospects and challenges on pattern of Nigerian firms' marketing activities in the global market. Nigeria's desire to attain the economic vision of 202020 (being among 20 top Global Economies in the Year 2020) will be enhanced and achieved; if the findings of this study are professionally and sincerely pursued, and what it can contribute to the nation's development is positively considered by stakeholders.
\end{abstract}

Keywords: Export marketing, Configuration, Global market.

Received: 8 December 2013/ Revised: 22 January 2014/ Accepted: 3 May 2014/ Published: 20 May 2014

\section{INTRODUCTION}

In developed and less develop countries of the world today; there exists an unhidden desire to sell goods and even services across national boundaries of the manufacturing countries. It is important to state that since the late 1980s, Nigerian government and organizations tend to see the need to export their goods and services across national frontiers. This is partly because of the contribution of export to nations' wellbeing and the intense economic/technological exchanges in 
the modern world (Opara, 2010). Export marketing in most developed nations were credited to have contributed immensely towards creating a borderless world, hence the recent saying that "the world has become one global village" (Ogwo, 1998).

Sequel to the immense benefits derived from export marketing and the emerging business opportunities worldwide, which are also associated with the current trends in global trade liberalization in most nations. Foreign trade or Export marketing brings about earning foreign exchange, increase in sales, increase in profit, lower production cost, employment creation, international recognition, enhancing reputation, improving living standard of exporting and importing nations and firms. In a study of China's exporting strategy it was found that, export was key to high GDP growth rate (Panaganniya, 1995).

The critical economic situations in most developing nations like Nigeria in the late 1980s; stimulated alternative search to crude oil as a major economic earner and development. Hence, the introduction of "Structural Adjustment Programme" (SAP), in 1986 by the then Federal Government of Nigeria. The fall in world price of crude oil at this time among other export challenges seriously affected the foreign earnings and infrastructural development of Nigeria. This is because over $70 \%$ of the countries earning was derived from crude oil export (Nigerian Export Promotion Council, 2009).

This study therefore, is to analyze the Nigerian firms' export marketing configuration (behavior) in the global market with a view to appreciate its contribution to Nigeria economic development. The outcome of this study will be useful to policy makers/implementers, academia and exporting firms as it will suggest how to facilitate/improve Nigerian export marketing in the Global market.

\section{REVIEW OF LITERATURE}

Theories are building blocks used to expand and understand research work, and help to give credence to studies of this nature. This is exemplified by several studies like those of Opara (2010), Onah (2009), Babakus and Yavas (2006), Testfom and Lntz (2006); which highlighted factors that determine the export behavior of manufacturing firms and the significant role export play in developing and developed countries. These studies found that decision to export depend on factors that are either external and or internal to the firms.

The external exporting factors found to be influential to the export decisions were Government Incentives, Polices Market Opportunities, Competition, Export Barriers, government export stimulation measures among others. Similarly internal factors found to play important role in the firm's decision to export include firms' number of years, company size and number of employees (William and Shaw, 2000; Testfom and Lntz, 2006). It is important to note however, that other empirical findings of previous studies have not been consistent on this issue. Some studies found a correlation between firm size and desire to export for small firms, but after a certain size this correlation does not hold (Cavusgil, 1984; Ogunusi, 1986). Very small companies 
do not intend to export. Furthermore, firms with nationwide operations in their home markets were found to be more willing to export than firms with local operations.

It is important to state that export has been noted to be nations' facilitator of economic development and sustainer. Hence, Export market behaviour of manufacturing firms has been the focus of several research interests of developed countries, like U.S.A, Britain, Germany, Scandinavian, etc. since the 1960s (Karafakioglu and Harcar, 1990). But similar attempts in developing countries, particularly Nigeria, have remained limited and/or inaccessible even in the recent years.

The Nigerian export marketing system, unlike that of developed countries of U.S.A., Britain, France, Germany, China etc. is characterized by the following limiting factors: political and policy uncertainties, Security challenges, and cultural life-styles (Onah, 2009). As barriers in Western Europe and elsewhere diminish, more and more companies have found attractive opportunities for expansion in countries other than their traditional home markets. Despite the urge to sell abroad and its benefits, there is little factual information about Nigerian firms export behavior and the significance to the nation's economic development, hence the need for this study.

\section{CONCEPTUAL FRAMEWORK FOR ANALYSING EXPORT MARKETING CONFIGURATION (EMC)}

The conceptual framework as illustrated in figure 1 below shows factors or variables that constitute external (ED) and internal determinants (ID), which may positively or negatively impact on the export marketing configuration (behavior) of Nigerian exporting firms in the global market. Experimental, Active and Committed firms (EMC) are the firms' manifest export marketing involvement, which are also influenced by Exporting Factors (EF).

The Experimental firms are characterized by new entry into export market through unsolicited inquiries or orders. They are new in export market, export sales, and may not account for more than $10 \%$ of total sales. They pay little attention to export, and employ product and pricing strategies that are not completely different with that of their domestic marketing. Firms' objectives here are more of short term.

Active firms are exporting firms that appreciate the importance of exporting towards achieving corporate goals. Firms here make long term commitment to export marketing, and channel un-used capacity to export. Product and price are designed to meet needs of overseas customers. Firms here also have some experience or years in exporting and plan for export marketing.

The Committed firms are in the final stage of export evolutionary process. Firms here conduct research and create business opportunities in foreign markets, make direct investment in foreign markets. They establish sales/subsidiaries or divisions which assume responsibilities in their overseas trading. Committed firms have long term corporate goals. 
Figure-1. Conceptual Framework for Analyzing Export Marketing Configuration (EMC)

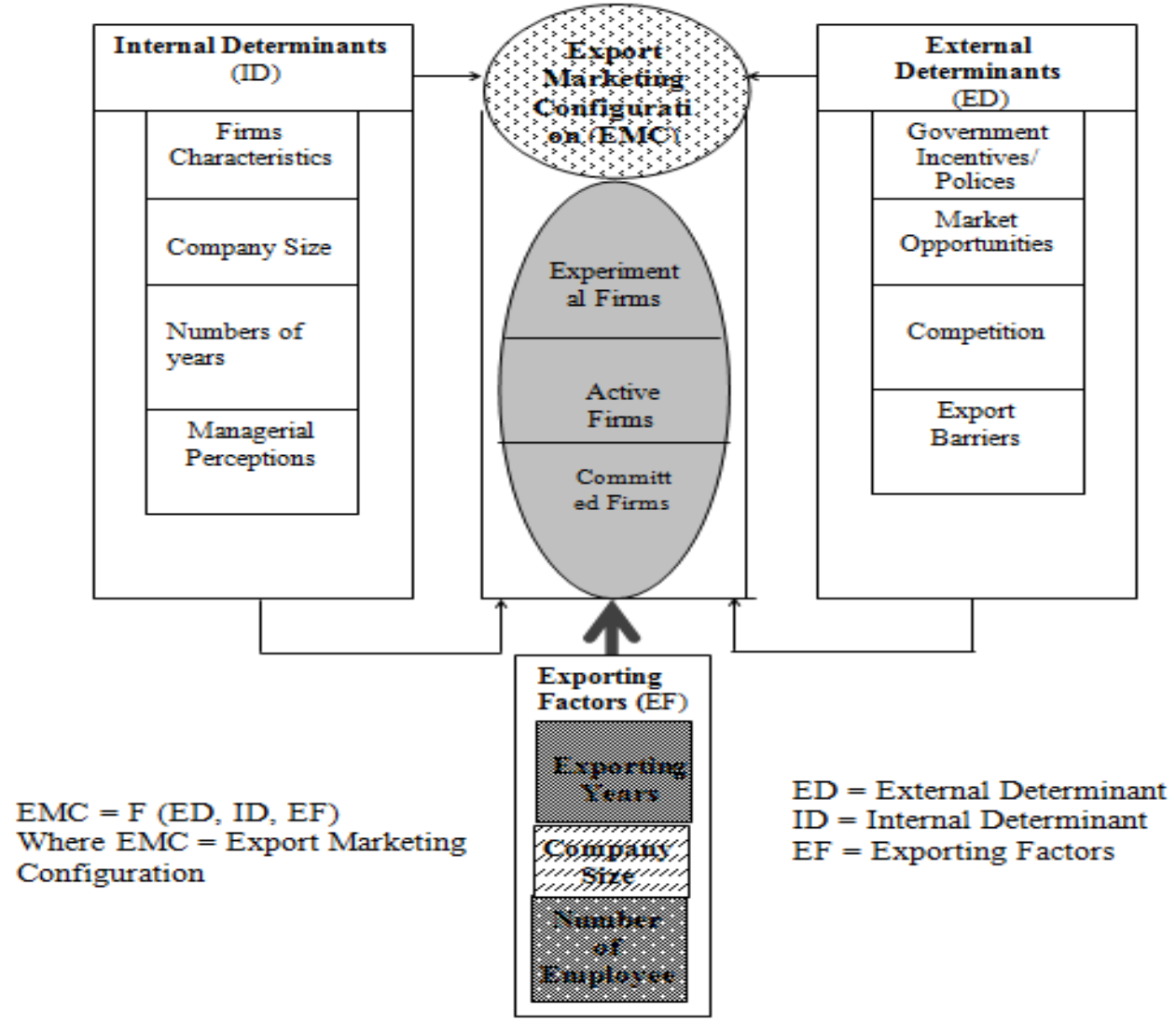

\section{STUDY METHODOLOGY}

The primary research data was derived from a survey of sixty functional exporting firms located in Lagos. These firms were the active manufacturing companies involved in export marketing and operated within Lagos as published by Nigerian Export Promotion Council (2009).

The instrument for data collection was a structural questionnaire administered to the most Senior Marketing Managers of the companies, after a pretest sampling of ten exporting firms located in Ikeja.

Questions in our study questionnaire were designed in simple, concise and with defined study objectives, meant to elicit adequate research information that enhanced the validity of this study. The data generated through the said questionnaire were statistically subjected to T-test Statistics, employing the Analysis of Variance (ANOVA) in the Statistical Packages for Social Science (SPSS), with a view of achieving the research objectives of characterizing Nigerian firms export marketing. 


\section{DATA ANALYSIS AND DISCUSSION OF FINDINGS}

The research data generated from questionnaire responses of respondents showed that the companies export involvement are categorized into Experimental, Active and Committed firms.

The manifest behavior of respondents firms asked to identity under what category of exporting their companies can be classified - Experimental, Active or Committed firms. The responses showed Experimental firms as 20 or $33.3 \%$, while Active firms are 26 or $46.7 \%$ and committed firms recorded 12 or $20 \%$. The data on the export involvement of Nigerian manufacturing firms above showed more Active and Experimental exporting firms than committed firms.

The responses confirmed that Nigerian manufacturing firms can be configured into Experimental, Active and Committed firms as shown in figure 2 and table 1.

Figure-2. Pie chart showing Exporting firms' degree of export involvement

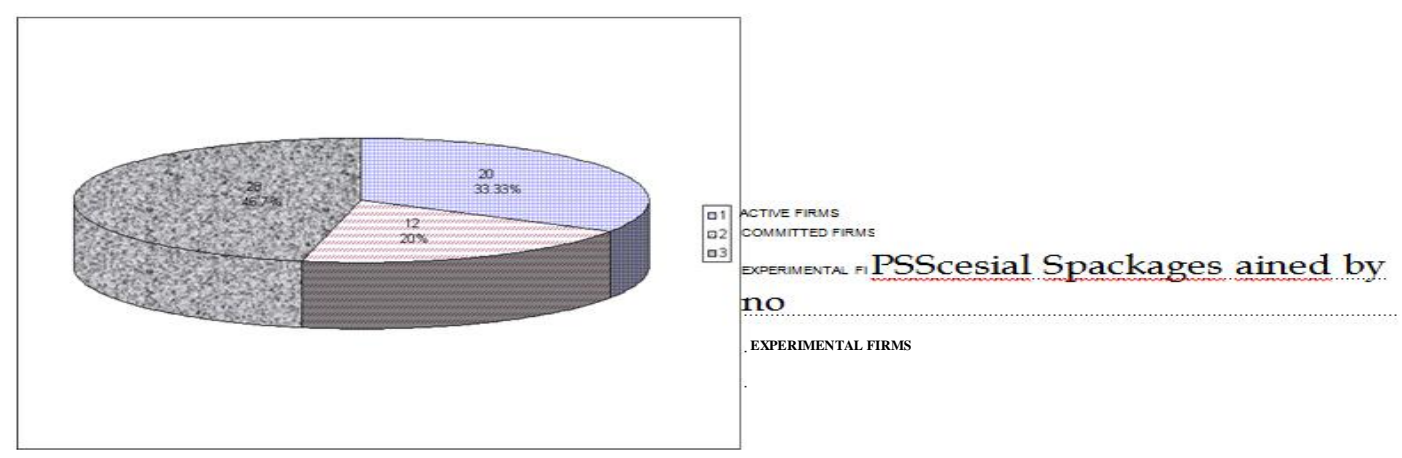

Note: SPSS Decision Rule: If significant value (calculated) is less th

significant difference otherwise, no significant difference.

Table-1. Exporting firm's Years of Export Involvement

\begin{tabular}{lllll}
\hline $\begin{array}{l}\text { Exporting firm's Years of Export } \\
\text { Involvement }\end{array}$ & Frequency & Percent & Valid percent & Cumulative percent \\
\hline Valid < 5 YEARS & 18 & 30.0 & 30.0 & 30.0 \\
5-10 YEARS & 14 & 23.3 & 23.3 & 53.3 \\
1-20 YEARS & 11 & 18.3 & 18.3 & 71.7 \\
> 20 YEARS & 17 & 28.3 & 28.3 & 100.0 \\
Total & 60 & 100.0 & 100.0 & \\
\hline
\end{tabular}

5.1. Regression Analysis of Degree of Export Involvement and Exporting Firms' Years of Export Involvement are Shown Below.

Table-2. Model Summary

\begin{tabular}{lllll}
\hline Model & R & R Square & $\begin{array}{c}\text { Adjusted } \\
\text { R Square }\end{array}$ & Std. Error of the Estimate \\
\hline 1 & $.941^{\mathrm{a}}$ & .885 & .883 & .266 \\
\hline
\end{tabular}

a. Predictors: (Constant), Exporting firm's Years of Export Involvement 
Table-3. Coefficients ${ }^{a}$

\begin{tabular}{lllllll}
\hline Model & & $\begin{array}{l}\text { Unstandardized } \\
\text { Coefficients }\end{array}$ & & $\begin{array}{l}\text { Standardized } \\
\text { Coefficients }\end{array}$ & T & Sig. \\
\hline & & B & Std. Error & Beta & & \\
\hline $1 . \quad \begin{array}{l}\text { (Constant) } \\
\text { firm's Years } \\
\text { Involvement }\end{array}$ & $\begin{array}{l}\text { Exporting } \\
\text { of Export }\end{array}$ & .438 & .079 & & 5.561 & .000 \\
& & .610 & 0.29 & .941 & 21.125 & .000 \\
\hline
\end{tabular}

a. Dependent Variable: Degree of Export involvement

Coefficient of determination $\mathrm{R}^{2}=0.885$. This implies that $88.5 \%$ of the variations in exporting firms' degree of export involvement is explained by the exporting firms' years of export involvement $(\mathrm{DEI}=0.438+0.610 \mathrm{EFYEI})$. The researcher therefore accepts the alternative hypothesis which states that exporting firms' years of export involvement (EFYEI) influence the degree of export involvement (DEI).

More so, the correlation value of 0.941 shows a very high relationship between the variables: years of export involvement and degree of export involvement. The t-value of 21.125 is high, and there is a corresponding significant value of 0.000 which is lower than 0.05 level of significance hence this is consistent with alternative hypothesis. This study findings showed that firms' length of experience in exporting by Experimental firms are more for less than five years, while Active firms' are more for between five years to ten years in export marketing. In other words, export marketing behavior of Nigerian firms is influenced by their number of years in exporting.

This finding implies that a natural process, over time, from Experimental to Active to Committed stages of export marketing will evolve. Cavusgil (1984) similarly, found a weak association between exporting and exporting experience. The study however, showed directional tendencies for Experimental firms to have less / more than twenty years of exporting experience. The study concluded that export experience is not a strong predictor of internationalization.

Table-4. Company Size

\begin{tabular}{lllll}
\hline Company Size & Frequency & Percent & $\begin{array}{l}\text { Valid } \\
\text { Percent }\end{array}$ & Cumulative Percent \\
\hline Valid Small & 2 & 3.3 & 3.3 & 3.3 \\
Medium & 36 & 60.0 & 60.036 .7 & 63.3 \\
Large & 22 & 36.7 & 100.0 & 100.0 \\
Total & 60 & 100.0 & & \\
\hline
\end{tabular}

5.2. Regression Analysis of Degree of Export Involvement and Company Size

Table-5. Model Summary

\begin{tabular}{lllll}
\hline Model & R & R Square & $\begin{array}{c}\text { Adjusted } \\
\text { R Square }\end{array}$ & Std. Error of the Estimate \\
\hline 1 & $.777^{\mathrm{a}}$ & .603 & .597 & .494 \\
\hline a. & Predictors: (Constant), Company' size & &
\end{tabular}


Table-6. ANOVA ${ }^{b}$

\begin{tabular}{|c|c|c|c|c|c|c|}
\hline \multicolumn{2}{|c|}{ Model } & $\begin{array}{l}\text { Sum of } \\
\text { Square }\end{array}$ & Df & $\begin{array}{l}\text { Mean } \\
\text { Square }\end{array}$ & $\bar{F}$ & Sig. \\
\hline \multirow[t]{3}{*}{1.} & Regression & 21.564 & 1 & 21.564 & 88.270 & $.000^{\mathrm{a}}$ \\
\hline & Residual & 14.169 & 58 & .244 & & \\
\hline & Total & 35.733 & 59 & & & \\
\hline
\end{tabular}

a. Predictors: (Constant), Company' size

b. Dependent Variable: Degree of Export Involvement

Table-7. Coefficients ${ }^{\mathrm{a}}$

\begin{tabular}{rllllll}
\hline Model & & $\begin{array}{l}\text { Unstandardized } \\
\text { Coefficients }\end{array}$ & & $\begin{array}{l}\text { Standardized } \\
\text { Coefficients }\end{array}$ & T & Sig. \\
\hline & & $\mathrm{B}$ & $\begin{array}{l}\text { Std. } \\
\text { Error }\end{array}$ & Beta & & \\
\hline 1. & (Constant) & -669 & .284 & & -2.354 & .022 \\
& Company' size & 1.115 & .119 & .777 & 9.395 & .000 \\
\hline
\end{tabular}

The coefficient of determination $(\mathrm{R} 2)=0.603$ shows that $60.3 \%$ variation in the degree of export involvement is explained by company size $(\mathrm{DEI}=-0.669+1.115 \mathrm{CS})$. Hence, the researcher accepts the alternative hypothesis which states that company size (CS) impact on degree of export involvement (DEI).

Firms' size and the quality of top management were found to play an important role in the firm's decision to export (Panaganniya, 1995). However, other empirical findings of previous studies have not been consistent on this issue; as very small companies do not tend to export (William and Shaw, 2000; Testfom and Lntz, 2006). Cavusgil (1984), found a correlation between firm size and desire to export for small firm, but after a certain size the correlation does not hold. Furthermore, firms with nationwide operations in their home markets were found to be more willing to export than firms with local operations William and Shaw (2000).

Another finding revealed that most of the manufacturing firms that export are large firms, or firms that engage more number of people. This finding is consistent with that of Karafakioglu and Harcar (1990), which also revealed that large firms are significantly more interested to export than smaller firms. Paweł (2006) corroborated this view as they affirm that firms' size is a major determinant on its initial interest and involvement in export marketing.

Table-8. Number of Employees

\begin{tabular}{cllll}
\hline No. of Employees & Frequency & Percent & $\begin{array}{l}\text { Valid } \\
\text { Percent }\end{array}$ & $\begin{array}{l}\text { Cumulative } \\
\text { Percent }\end{array}$ \\
\hline Valid < 10 Employment & 2 & 3.3 & 3.3 & 3.3 \\
10-24 Employment & 2 & 3.3 & 3.3 & 6.7 \\
25-50 Employment & 17 & 28.3 & 28.3 & 35.0 \\
> 50 Employment & 39 & 65.0 & 65.0 & 100.0 \\
Total & 60 & 100.0 & 100.0 & \\
\hline
\end{tabular}


Table-9. Model Summary

\begin{tabular}{lllll}
\hline Model & $\mathbf{R}$ & R Square & $\begin{array}{l}\text { Adjusted } \\
\text { R Square }\end{array}$ & Std. Error of the Estimate \\
\hline 1 & $.729^{\mathrm{a}}$ & .531 & .523 & .537 \\
\hline
\end{tabular}

a. Predictors: (Constant), No. of Employees

Table-10.ANOVA

\begin{tabular}{clllllll}
\hline Model & & Sum & of & df & Mean Square & F & Sig. \\
& & Square & & & & & \\
\hline \multirow{2}{*}{ 1. } & Regression & 18.983 & 1 & 18.983 & 65.734 & $.000^{\text {a }}$ \\
& Residual & 16.750 & 58 & .289 & & \\
& Total & 35.733 & 59 & & & \\
\hline
\end{tabular}

a. Predictors: (Constant), No. of Employees

b. Dependent Variable: Degree of Export Involvement

Table- 11.Coefficients ${ }^{\mathrm{a}}$

\begin{tabular}{llllll}
\hline Model & $\begin{array}{l}\text { Unstandardized } \\
\text { Coefficients }\end{array}$ & & Standardized Coefficients & T & Sig. \\
\hline & B & Std. Error & Beta & & \\
\hline $1 . \quad$ (Constant) & -851 & .350 & & 2.430 & .018 \\
No. of Employees & .784 & .097 & .729 & 8.108 & .000 \\
\hline
\end{tabular}

a. Dependent Variable: Degree of Export involvement

Coefficient of determination $\mathrm{R} 2=6.531$. This implies that $53 \%$ variation in degree of export involvement is explained by number of employees. Hence, $(\mathrm{DEI}=-0.851+0.784 \mathrm{NE})$ the researcher accepts the alternative hypothesis which states that there is a significant impact of number of employees on firms export involvement (e.g. experimental, active, committed).

\section{CONCLUSIONS AND IMPLICATIONS}

It is important to state that Nigeria has the comparative advantage to produce several products, and market them not only to other African countries, but also to developed countries. However, in spite of the country's product advantage and various export potentials, exporting firms are yet to fully exploit the derivable benefits. This is because Nigerian exporting firms have not taken into consideration the fact that firms years in export influence their pattern of export, just as company size and number of employees' impact on exporting firms' categorization. The implication of this study is that, Nigeria attainment of the desired economic target of 202020 (being among the first 20 Global economies in the year 2020) will be achieved if: Nigerian policy makers/implementers and exporting firms practically and sincerely appreciate the importance and role of export marketing to nation's development - as highlighted in this study. That is, attainment of the vision will be enhanced when firms' years of export involvement which influence their pattern (Experimental, Active, to Committed) of export as revealed in this study is appreciated. Similarly, Government needs to create the conducive atmosphere in terms of security, infrastructure, and policy consistency for exporting firms to achieve the desired objectives.

Funding: This study received no specific financial support.

Competing Interests: The author declares that there are no conflicts of interests regarding the publication of this paper. 


\section{REFERENCES}

Babakus, E. and U. Yavas, 2006. Perceived uncertainty, networking and export performance. European Business Review, $18(1): 4-13$.

Cavusgil, S.T., 1984. Differences among exporting firms based on their degree of internationalization. Journal of Business Research, 12: 52-63.

Karafakioglu, M. and T.D. Harcar, 1990. Internal determinants affecting interest in exporting companies. Journal of Global Marketing, 3(4): 17-19.

Nigerian Export Promotion Council, 2009. Why export. Lagos: Federal Government Printing Press.

Ogunusi, G., 1986. Nigerians, export policy management in Nigeria. Management in Nigeria, 34(2): 29-31.

Ogwo, E.O., 1998. Export marketing for Nigerians' economic transformation. Management in Nigeria, 34(2-4): 20-25.

Onah, J., 2009. A model of export promotion for Nigeria. Available from http://www.faqs.org/abstract/business.

Opara, B.C., 2010. Nigerian firms, non-oil export involvement: An economic transformation paradigm. European Journal of Social Sciences, 40(4): 547-556.

Panaganniya, A., 1995. What can we learn from China's export strategy? Finance \& Development: 32-35.

Paweł, B., 2006. Newly industrialized, globalization and the transformation of foreign economic policy. London: Ashgate Publishing Ltd.

Testfom, G. and E. Lntz, 2006. A classification of export marketing problems of small and medium size manufacturing firms in developing countries. International Journal of Emerging Markets, 1(3): 262-269.

William, L. and E.H. Shaw, 2000. Executive insights: Global marketing management at the dawn of the new millennium. Journal of International Marketing, 8(1): 65-77.

\section{BIBLIOGRAPHY}

Barker, M.J. and K. El-Din, 1991. Competitive success through marketing: The case of Japanese manufacturing firms in the U.K. Journal of Euro Marketing, 1: 35-48.

Egwuatu, B.S.C., 2008. Reducing poverty through better credit delivery: The Asian experience. Bullion, 32(1): 8-16.

Iwok, E.R., 1986. The prospect of made-in-Nigeria goods in world market. The Journal of Management Sciences: 23-27.

Kingsley, J., 1988. Marketing in developing countries. London: Macmillan Education Ltd.

Nigerian Export Promotion Council, 1997. Export incentives in Nigeria. Lagos: Federal Government Printing Press.

Opara, B.C., 2004. Barriers to Nigerian manufacturing firms' export marketing involvement. Journal of Industrial Business and Economic Research, 8(2): 278-286.

Wortzel, L.H. and H.V. Wortzel, 1981. Export marketing strategies for NIC and LDC based firms. Columbia Journal of World Business: 51-60.

Views and opinions expressed in this article are the views and opinions of the author(s), International Journal of Management and Sustainability shall not be responsible or answerable for any loss, damage or liability etc. caused in relation to/arising out of the use of the content. 